\title{
Effects of Sexually Activated Rams or Ewes on Pulsatile LH Secretion in Anoestrous Sheep
}

\author{
S. YILDIZ ${ }^{1, *}$, M. UZUN ${ }^{1}$, M. CENESIZ ${ }^{1}$, O. UCAR ${ }^{2}$, M. KAYA ${ }^{1}$, F. ONDER ${ }^{1}$ \\ Departments of Physiology ${ }^{1}$, and Reproduction and Artificial Insemination ${ }^{2}$, \\ Faculty of Veterinary Medicine, University of Kafkas, 36040 Kars, Turkey
}

Received March 29, 2002

Accepted June 19. 2002

\section{Abstract}

Yildiz S., M. Uzun, M. Cenesiz, O. Ucar, M. Kaya, F. Onder: Effects of Sexually Activated Rams or Ewes on Pulsatile LH Secretion in Anoestrous Sheep. Acta Vet. Brno 2002, 71: 297-302.

The aim of this study was to test whether anoestrous ewes respond differentially, in terms of pulsatile $\mathrm{LH}$ release, to sexually activated males or females. For that purpose, anoestrous ewes $(\mathrm{n}=$ 21) were divided into three equal groups and placed into three separated rooms. The experiment commenced two months before the expected breeding season. Body weights and body condition scores of ewes were recorded prior to the experiment. Into the Female group $(n=7)$, long-acting progestins plus oestradiol injected ewes $(n=4)$ were included; into the Male group $(n=7)$ longacting testosterone injected rams $(n=4)$ were included; and into the Control group $(n=7)$, sexually inactive ewes $(n=4)$ were introduced. In order to remove the between animal variance, blood samples for $\mathrm{LH}$ were taken twice, before and after the introduction, for $8 \mathrm{~h}$ at $15 \mathrm{~min}$ intervals. The results showed that mean and smoothed mean LH concentrations, $\mathrm{LH}$ pulse frequency, $\mathrm{LH}$ pulse amplitude and duration were not different between the experimental groups neither before nor after the introduction. However, when the LH data obtained before and after introduction were compared, it was seen that $\mathrm{LH}$ pulse frequency tended to decrease following the introduction in Female group $(P=0.078)$. Body weights and condition scores were not different between the groups but LH pulse frequency was higher in ewes that had condition scores higher than 2.00 units. Additionally, there was a significant positive correlation between condition score and LH pulse frequency $\left(P=0.004 ; \mathrm{R}^{2}=0.368\right)$. In conclusion, it appears that although female sheep tend to reduce LH pulse frequency of anoestrous ewes, body energy reserves appear to be the major effector of LH pulse frequency during the anoestrous period studied.

Testosterone, oestradiol, progestin, sexual interactions, body condition score

Photoperiod, nutrition, body energy reserves and social interactions are among the factors that affect the reproductive activity of the sheep (Adam and Robins on 1994; Yildiz et al. 2001; Yildiz et al. 2002a and 2002b). In spite of the difficulties in managing photoperiod, nutrition and body energy reserves, social manipulation of the reproductive activity in farm animals emerges as a good alternative, especially, to reproductive management techniques that facilitate application of reproductive hormones (Rekwot et al. 2001). Some of the pheromonal methods have been in use for many years as a result of their practicality. "Ram effect", which includes separation of rams from the ewe flock and their reunification after following 3-4 weeks, is an example of these methods (Martin et al. 1980, 1986; Lindsay 1996). By this way, anoestrous ewes are brought to cyclicity and hence reproductive activity of all flock is improved (Lucidi et al. 2001). This male-tofemale interaction is known to be accompanied by increased LH secretion in the ewes (Cohen-Tannoudji et al. 1986, 1989). On the other hand, it appears that a female-tofemale interaction might also occur in sheep (Zarco et al. 1995; Yildiz et al. 2002a). Zarco et al. (1995) found that anoestrous ewes in pens closer to the oestrous females showed a high degree of ovulation and similarly, in the study of Yildiz et al. (2002a),

Address for correspondence:

Dr. Sedat Yildiz

Kafkas Universitesi, Veteriner Fakültesi

36040 Kars, Turkey
Phone: +904742426846

e-mail: yildizsedat@hotmail.com

http://www.vfu.cz/acta-vet/actavet.htm 
females that were separated from the rams showed a good degree of synchronisation of their oestrous cycles.

The studies carried out in sheep, therefore, suggest that both male-to-female and femaleto-female interactions are possible. However, to the best of our knowledge, there is no study in which both types of interactions are investigated in terms of their effect on pulsatile LH secretion. Although ram effect is known to be very strong (Martin et al. 1986; CohenTannoudji et al. 1986, 1989), effect of an ewe on the LH secretion in other ewes is not known. Therefore the aim of the current study was to investigate, during the anoestrous season, the effects of sexually activated males or females on the pulsatile LH secretion characteristics in anoestrous ewes. For that purpose, (i) long-acting testesterone injected rams were used for male effect, (ii) long-acting progestin and oestradiol injected non-cycling ewes were used for female effect, and (iii) anoestrous ewes were used for control group.

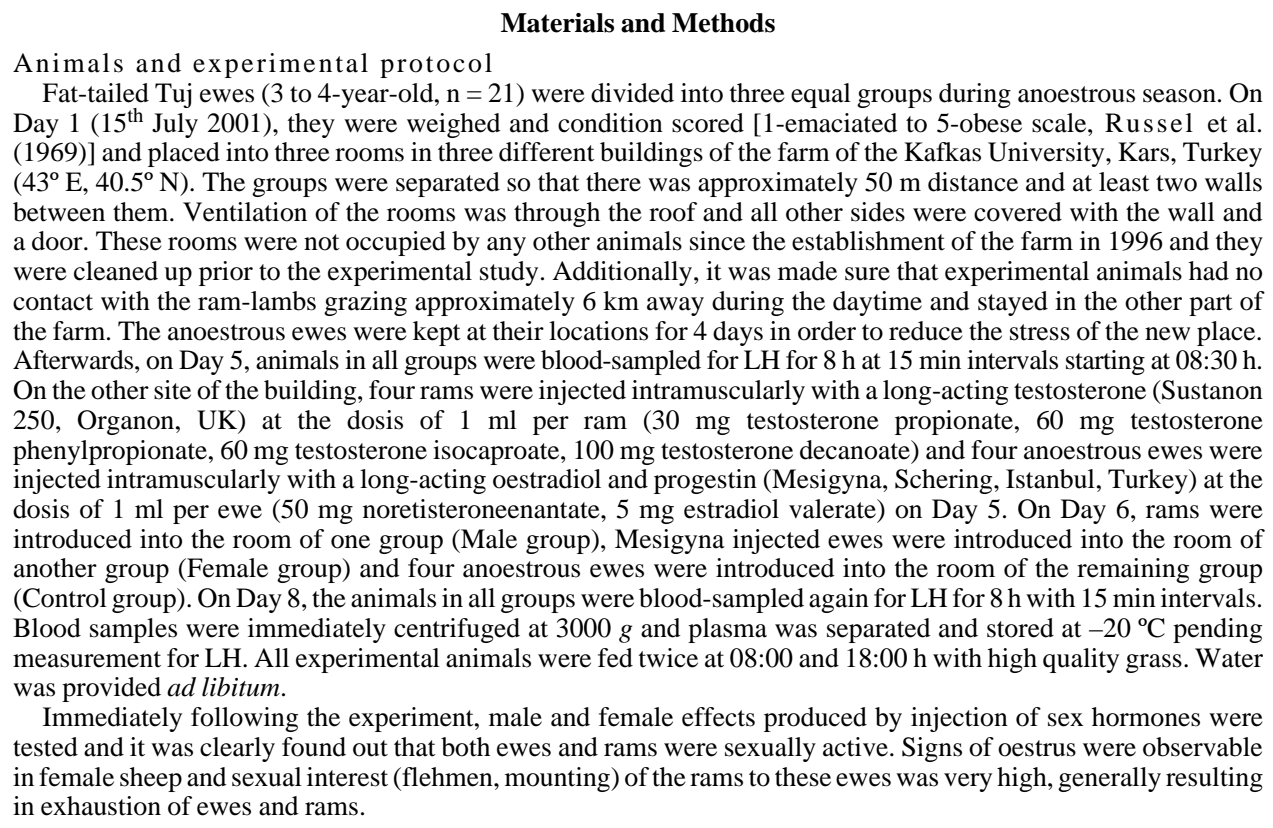

Enzyme immunoassay of LH samples

A sensitive competitive enzyme immunoassay method developed by Mutayoba et al. (1990) for bovine LH and modified by Yildiz et al. (2002b) was used to analyse LH concentrations. Briefly, D-Biotinyl- $\varepsilon$-aminocaproic acid N-hydroxy-succimidine ester (Biotin-X-NHS, SIGMA, Germany) was used for labelling oLH (NIDDK-oLHI-4 (AFP-8614B)). Affinity purified goat IgG antirabbit IgG was attached to the solid phase and labelled and nonlabelled (sample) oLH were competed against the anti-oLH raised in rabbit (NIDDK-anti-oLH-1 (AFP-192279)). Dilutions of biotinyl LH and oLH antiserum were found to be 1:5,000 for 1:3,200,000, respectively. Standards used in the current study were between $0.39-50 \mathrm{ng} \mathrm{oLH} / \mathrm{ml}$. The minimum detection limit of the assay was $0.70 \mathrm{ng} / \mathrm{ml}$. The intra-assay coefficients of variation were $8.5 \%$ and $6.4 \%$ and inter-assay coefficients of variation were $19.4 \%$ and $19.8 \%$ for the quality controls containing 4.1 and $10.0 \mathrm{ng} / \mathrm{ml} \mathrm{LH}$, respectively.

Analysis of LH results

EIA results of LH were analysed for numbers of pulses by using PC pulsar programme developed by Merriam and Wachter (1982). The G parameters (the number of standard deviation by which a peak must exceed the baseline in order to be accepted as pulse) were $3.0,2.6,2.2,1.8$, and 1.4 for $G_{1}-G_{5}$, these being the requirements for pulses composed of 1 to 5 successive samples that exceed the baseline, respectively. Smoothing time used was $480 \mathrm{~min}$. The Baxter parameters describing the parabolic relationship between the concentration of a hormone in a sample and the standard deviation (assay variation) about that concentration, obtained from a pool of samples, were $0.086\left(b_{1}\right.$, the $y$ intercept $), 0.11\left(b_{2}\right.$, the $x$ coefficient $)$ and $0.0014\left(b_{3}\right.$, the $\chi^{2}$ coefficient $)$. 
Statistical analyses

Body weight, BCS, and LH data taken at the first and second samplings were compared separately using Generalised Linear Models within the MINITAB statistical package (MINITAB Inc, Pennsylvania, USA) by using the experimental groups as factors. For comparison of the first and second samplings, however, paired t-test was used without taking into account the experimental groups. Paired t-test was also used separately for each experimental group to find out the differences that might have occurred between the first and second samplings. Linear regressions within MINITAB statistical package were used to find out the relationships between LH data and BCS. Data are presented as mean \pm S.E.M.

\section{Results}

Body weight and BCS

Body weights were $55 \pm 2.6,60 \pm 2.3$ and $59 \pm 3.5 \mathrm{~kg}$ for Female, Male and Control groups, respectively $(P>0.05)$. BCS were $2.1 \pm 0.2,2.4 \pm 0.2$, and $2.3 \pm 0.1$ units for Female, Male and Control groups, respectively $(P>0.05)$.

\section{LH data}

Mean and smoothed mean LH concentrations, LH pulse frequencies, amplitudes and durations are given in Table 1 for the first (before introduction) and second (after introduction) samplings. Paired t-test was used to find out whether there had been a change in LH data between the samplings carried out before and after the introductions. However, no difference was observed in LH data but LH pulse frequency tended to decrease in Female groups $(P=0.078)$, whereas it increased non-significantly in Male and Control groups.

Table 1

Pulsatile LH secretion characterisitics of anoestrous ewes before or after the introduction of sexually-activated females (Female group) or males (Male group) or sexually inactive females (Control group). No statistical differences were observed between the groups neither before nor after the introduction. Values represent mean \pm S.E.M.

\begin{tabular}{|c|c|c|c|c|c|c|}
\hline & \multicolumn{2}{|c|}{ Control group } & \multicolumn{2}{c|}{ Female group } & \multicolumn{2}{c|}{ Male group } \\
\hline & Before & After & Before & After & Before & After \\
\hline Mean LH concentration $(\mathrm{ng} / \mathrm{ml})$ & $1.6 \pm 0.1$ & $1.7 \pm 0.2$ & $1.4 \pm 0.1$ & $1.5 \pm 0.1$ & $1.4 \pm 0.1$ & $1.1 \pm 0.2$ \\
Smoothed mean LH conc. $(\mathrm{ng} / \mathrm{ml})$ & $1.6 \pm 0.1$ & $1.6 \pm 0.2$ & $1.3 \pm 0.1$ & $1.3 \pm 0.2$ & $1.4 \pm 0.1$ & $1.1 \pm 0.2$ \\
LH pulse frequency/ 8 h & $0.43 \pm 0.20$ & $0.71 \pm 0.29$ & $0.57 \pm 0.30$ & $0.14 \pm 0.14$ & $0.43 \pm 0.20$ & $0.57 \pm 0.43$ \\
amplitude (ng/ml) & $1.21 \pm 0.19$ & $1.89 \pm 0.07$ & $1.67 \pm 0.15$ & $1.62 \pm 0.19$ & $1.33 \pm 0.24$ & $1.66 \pm 0.68$ \\
duration (min) & $30 \pm 15$ & $23 \pm 8$ & $28 \pm 9$ & $15 \pm 6$ & $30 \pm 15$ & $28 \pm 13$ \\
\hline
\end{tabular}

Body weight appeared to be positively correlated to LH pulse frequency at the first sampling $\left(\mathrm{R}^{2}=0.158 ; P<0.08\right)$ and this relationship became even much stronger at the second sampling $\left(\mathrm{R}^{2}=0.339 ; P<0.01\right)$. Similarly, BCS was positively correlated to LH pulse frequency at the first $\left(\mathrm{R}^{2}=0.266 ; P<\right.$ $0.05)$ and at the second $\left(\mathrm{R}^{2}=0.267 ; P<0.05\right)$ samplings. However, even a stronger relationship was observed between BCS and mean LH pulse frequency of the first and second samplings (Fig. 1). Additionally, ewes having a BCS less or equal to 2.00 units had lower $\mathrm{LH}$ pulse frequencies at the first $(0.25$ \pm 0.16 vs $0.62 \pm 0.18$ pulses $/ 8 \mathrm{~h} ; P>0.05)$ and

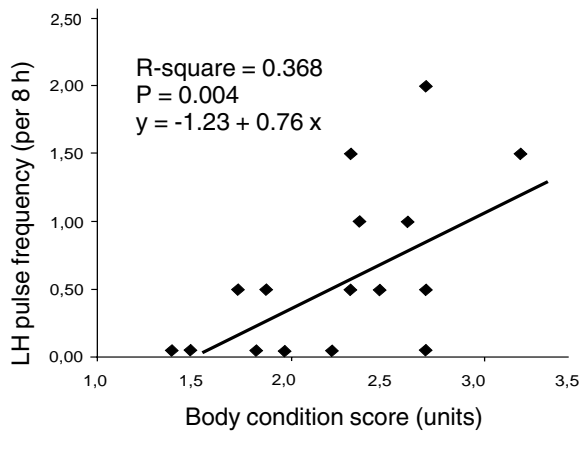

Fig. 1. The relationship between BCS and mean LH pulse frequency for the first and second sampling periods. Linear regression lines best described the data, $n=21$ (some points overlap). 
second $(0.00 \pm 0.00$ vs $0.77 \pm 0.26$ pulses / $8 \mathrm{~h} ; P<0.05)$ samplings and when the mean $\mathrm{LH}$ pulse frequencies of the first and second samplings were taken into account $(0.13 \pm 0.08 v \mathrm{~s}$ $0.69 \pm 0.18$ pulses $/ 8 \mathrm{~h} ; P<0.05)$.

\section{Discussion}

The present experiment shows that, compared to the female or male effects, body energy reserves appear to be the main regulator of pulsatile LH secretion in ewes during the anoestrous period studied. It has been reported that BCS is positively correlated to timing of LH surge in sheep (Yildiz et al. 2002b) and LH pulse frequencies in sheep (Robinson 1990) and cattle (Yildiz et al. 1997). The link between BCS and hypothalamus, where GnRH secretion is initiated, appear to include leptin secretion from the adipose tissue (Blache et al. 2000; Yildiz et al. 2001) since leptin informs the hypothalamus about the sufficiency of energy stores for the initiation of reproductive activity (B lache et al. 2000). It appears from the current study that, in fat-tailed sheep breed, which might differ in adipose tissue deposition and mobilisation, LH pulse frequency is also well correlated with BCS.

LH pulse frequencies did not differ between the groups during the second sampling. In other words, there were no significant differences between the Male and Female groups and the control group. Various reasons might be considered in that respect. First, it appears that the current study was carried out during the period that coincided with the start of replenishment of the pituitary LH stores in anoestrous season. However, there were still approximately two months for the commencement of breeding season for that breed (Yildiz et al. 2002a) and LH pulses were therefore low. Probably this prevented the observation of differences between the groups as a result of lower LH pulse frequency. Additionally, Ro s a et al. (2000) reported that numbers of ewes ovulating in response to ram effect were higher when the rams were implanted with melatonin. This suggest that season is an important part of sexual interactions. Secondly, for the Male group, it was not possible to induce sex effects due to the short period of introduction. Normally a male effect would be observed after a long period of separation that is 3-4 weeks (Martin et al. 1986). However, female effects are likely to occur within short periods and there might be no need for separation for the observance of female effects. As evidenced in women, the odourless compounds taken at different stages of oestrous cycles have differential effects in the recipient women (Stern and McClintock 1998; Weller 1998). Therefore, it appears that female effects might occur within a short period of time. In the current study, in order to be able to compare the male and female effects, we tended to introduce rams after short separation. By this way, short-term results for both male and female effects could be determined. However, the results obtained suggest little or no effect.

Sampling the ewes twice, before and after the introduction, helped to remove betweenanimal variances that could occur. The results of the paired $t$-test revealed that LH pulse frequency tended to drop in the Female group, suggesting a negative role of a cycling ewe on the anoestrous ewes. This is in contrast to the findings of Zarco et al. (1995) who observed a positive effect of cycling ewes on the anoestrous ewes. In fact, two mechanisms might be postulated in terms of female-to-female effect: (1) a ewe might give a positive signal to the other ewes in the flock and hence might advance the timing of their ovulations, or (2) a ewe might give a negative signal to the other ewes to postpone their ovulation and hence they might be within the synchronous cycling group in the next ovulation. The results obtained in the current study are in line with the latter, whereas the study of Zarco et al. (1995) is in line with the first hypothesis. In a study carried out by our group we observed, in female-introduced ewes, a delay in preovulatory LH surges following progestagen sponge removal (unpublished data). This might support the negative signal hypothesis. In fact, under the farm conditions, where the numbers of animals at each stage of oestrous cycle is 
normally different, both hypotheses might be true. For example, an oestrous ewe might give positive signal to a recipient ewe if she is in late luteal or follicular period but might give negative signals to early or mid-luteal ewes. Similar hypotheses might be postulated for the times preceding the breeding season. However, further studies are required to find out the interactions between ewes at different stages of anoestrous season or oestrous cycle.

In conclusion, sexually activated ram introduction for short durations did not yield in significant positive effects on pulsatile LH secretion whereas sexually activated ewe introduction tended to negatively affect LH pulsatility in anoestrous ewes two months before breeding season. In fact, during this period, body energy reserves appeared to be the main effector of pulsatile LH release.

\section{Vliv sexuální aktivace beranů nebo bahnic v závislosti na rytmu sekrece LH v anestru ovcí}

Cílem studie bylo zjistit, zda bahnice v anestru reagují odlišně na přítomnost sexuálně aktivovaných samců a samic. Jejich reakce byla měřena pomocí rytmu pulzatilního uvolňování LH. Za tímto účelem byly ovce v anestru $(n=21)$ rozděleny do tří stejných skupin a umístěny do tří oddělených místností. Experiment začal dva měsíce před očekávanou reprodukční sezónou. Před experimentem byla zaznamenána tělesná hmotnost a kondiční skóre ovcí. Ke skupině samic $(n=7)$ byly zařazeny 4 bahnice, kterým byl injekčně aplikován dlouhodobě působící progesteron a estradiol; ke druhé skupině $(n=7)$ byli přidáni 4 berani, jimž byl injekčně aplikován dlouhodobě působící testosteron; a ke kontrolní skupině $(\mathrm{n}=7)$ byly zařazeny 4 pohlavně neaktivní bahnice. Abychom vyloučili individuální variabilitu naměřených hodnot LH, byly vzorky krve na jeho stanovení odebrány dvakrát, před a po introdukci do pokusných skupin, a to po dobu 8 hodin v 15 minutových intervalech. Výsledky ukázaly, že mezi experimentálními skupinami nebyly rozdíly v koncentraci LH (průměr a vyhlazený průměr), frekvenci pulzů LH, v amplitudě a trvání pulzů LH, před a po vystavení bahnic přítomnosti sexuálně aktivovaných zviřat. Avšak po porovnání získaných výsledků LH před a po introdukci aktivovaných jedinců byl ve skupině samic patrný klesající trend $(\mathrm{P}=$ 0.078) ve frekvenci pulzů LH. Tělesná hmotnost ani kondiční parametry se mezi skupinami nelišily, avšak frekvence pulzů LH byla vyšší v ovcí s tělesným skóre vyšším než 2.00 jednotky. Navíc byla nalezena signifikantní pozitivní korelace mezi frekvencí pulzů LH a kondičním stavem $\left(P=0.004 ; \mathrm{R}^{2}=0.368\right)$ bahnic. $\mathrm{Z}$ výsledků studie vyplývá, že $\mathrm{v}$ přítomnosti aktivovaných ovcí inklinují bahnice $\mathrm{v}$ anoestru ke snížení frekvenci pulzů LH, největší vliv na tuto frekvenci během fáze anoestru mají zřejmě jejich energetické zásoby.

\section{Acknowledgement}

This study was supported by TUBITAK (The Technical and Scientific Research Council of Turkey, Project No: VHAG-1794/ADP). We wish to thank Dr. A.F. Parlow and NIDDK for the provision of LH antigene and antibody. We would also like to thank to the veterinary students who helped with the design of the experimental units.

\section{References}

ADAM, CL, ROBINSON, JJ 1994: The role of nutrition and photoperiod in the timing of puberty. Proc Nutr Soc 23: $89-102$

BLACHE, D, TELLAM, RL, CHAGAS, LM, BLACKBERRY, MA, VERCOE, PE, MARTIN, GB 2000: Level of nutrition affects leptin concentrations in plasma and cerebrospinal fluid in sheep. J Endocrinol 165: 625-637 COHEN-TANNOUDJI, J, LAVENET, C, LOCATELLI, A, TILLET, Y, SIGNORET, JP 1989: Non-involvement of accessory olfactory system in the LH response of anoestrous ewes to male odour. J Reprod Fertil 86: 135-144. COHEN-TANNOUDJI, J, LOCATELLI, A, SIGNORET, JP 1986: Non-pheromonal stimulation by the male of LH release in the anoestrous ewe. Physiol Behav 36: 921-924

LINDSAY, DR 1996: Environment and reproductive behaviour. Anim Reprod Sci 42: 1-12

LUCIDI, P, BARBONI, B, MATTIOLI, M 2001: Ram-induced ovulation to improve artificial insemination efficiency with frozen semen in sheep. Theriogenology 55: 1797-1805 
MARTIN, GB, OLDHAM, CM, LINDSAY, DR 1980: Increased plasma LH levels in seasonally anovular merino ewes following the introduction of rams. Anim Reprod Sci 3: 125-132

MARTIN, GB, OLDHAM, CM, COGNIE, Y, PEARCE, D 1986: The physiological responses of anovulatory ewes to the introduction of rams: A review. Livestock Prod Sci 15: 219-247

MERRIAM, GR, WACHTER, KW 1982: Algorithms for the study of episodic hormone secretion. Am J Physiol 243: E310-318

MUTAYOBA, BM, MEYER, HDD, SCHAMS, D, SCHALLENBERGER, E 1990: Development of a sensitive enzyme immunoassay for LH determination in bovine plasma using the streptavidin-biotin technique. Acta Endocrinologica (Copenh) 122: 227-232

REKWOT PI, OGWU, D, OYEDIPE, EO, SEKONI, VO 2001: The role of pheromones and biostimulation in animal reproduction. Anim Reprod Sci 65: 157-170

ROBINSON, JJ 1990: Nutrition in the reproduction of farm animals. Nutr Res Rev 3: 253-276

ROSA, HJ, JUNIPER, DT, BRYANT, MJ 2000: Effects of recent sexual experience and melatonin treatment of rams on plasma testosterone concentration, sexual behaviour and ability to induce ovulation in seasonally anoestrous ewes. J Reprod Fertil 120: 169-176

RUSSEL, AJF, DONEY, JM, GUNN, RG 1969: Subjective assessment of body fat in live sheep. J Agric Sci (Cambridge) 74: 451-454

STERN, K, McCLINTOCK, MK 1998: Regulation of ovulation by human pheromones. Nature 392: 177-179.

WELLER, A 1998: Communication through body odour. Nature 392: 126-127

YILDIZ, S, BLACHE, D, KAYA, I, CELEBI, F, SAATCI, M, GUVEN, B 2001: Effects of short-term high fat intake on body condition, weight and leptin concentrations in fat-tailed Tuj lambs. In $5^{\text {th }}$ Annual Conference of ESDAR, Vienna, p. 86

YILDIZ, S, GUVEN, B, COLAK, A, UZUN, M 2002a: Progesterone profiles of fat-tailed Tuj ewes following tactile and visual separation of rams in the beginning of breeding season. J Vet Med A 49: 132-136

YILDIZ, S, SAATCI, M, UZUN, M, GUVEN, B 2002b: Effects of ram introduction after the second prostaglandin $\mathrm{F}_{2}$ injection on Day 11 on the LH surge characteristics in fat-tailed ewes. Reprod Domest Anim (in press)

YILDIZ, S, SINCLAIR, KD, GEBBIE, FE, HUTCHINSON, JSM, BROADBENT, PJ 1997: The relationship between LH pulse frequency, ovarian folliculogenesis and body condition in post-partum beef cows. J Reprod Fertil, Abstract Series No:19:152

ZARCO, L, RODRIGUEZ, EF, ANGULO, MRB, VALENCIA, J 1995: Female to female stimulation of ovarian activity in the ewe. Anim Reprod Sci 39: 251-258 